ISSN : 1412-7601

Volume 3, No.2 September 2017

http://www.ekonobis.unram.ac.id

EKONOBIS

\title{
Dampak Pengembangan Pariwisata Terhadap Pendapatan Asli Daerah (PAD) Di Kabupaten Lombok Tengah, Nusa Tenggara Barat Tahun 2002-2016
}

\author{
Ihsan Rois, Luluk Fadliyanti, Bq.Saripta Wijimulawiani.
}

Universitas Mataram

\begin{tabular}{|c|c|}
\hline ARTICLE INFO & Received : 20 April 2017; Accepted: 15 Mei 2017; Published: September 2017 \\
\hline $\begin{array}{l}\text { Keywords : } \\
\text { Fund Balance.. }\end{array}$ & $\begin{array}{l}\text { ABSTRACT : This study aims to analyze the impact of tourism development on regional } \\
\text { original income in the district of Central Lombok. The data used in this study is time series } \\
\text { data for the period of 2002-2016 obtained from Region Income Broad, Tourism and } \\
\text { Culture Broad, and Statistic Broad of the Lombok Cental Region. The variables used in this } \\
\text { study are the number of tourists, the number of hotels and restaurants, the number of } \\
\text { attractions against and the average length of stay of region income in the district of } \\
\text { Central Lombok. Analyzer used multiple regression analysis using Ordinary Least Square } \\
\text { (OLS) method. }\end{array}$ \\
\hline $\begin{array}{l}\text { Kata Kunci: } \\
\text { Dana Perimbangan. }\end{array}$ & $\begin{array}{l}\text { ABSTRAK : Penelitian ini bertujuan untuk menganalisis dampak dari pengembangan } \\
\text { pariwisata terhadap Pendapatan Asli Daerah (PAD) pada kabupaten Lombok Tengah. } \\
\text { Data yang digunakan dalam penelitian ini dalah data runtun waktu periode tahun 2002- } \\
2016 \text { yang diperoleh dari Badan Pusak Statistik kabupaten Lombok Tengah, Dinas } \\
\text { Pariwisata dan Kebudayaan dan Dinas Pendapatan Kabupaten Lombok Tengah. Variabel } \\
\text { yang digunakan dalam penelitian ini adalah jumlah wisatawan, jumlah hotel dan restoran, } \\
\text { jumlah obyek wisata terhadap dan rata-rata lama menginap wisatawan Pendapatan Asli } \\
\text { Daerah (PAD) di kabupaten Lombok Tengah.Alat analisis yang digunakan analisis regresi } \\
\text { berganda dengan menggunakan metode Ordinary Least Square (OLS). Hasil penelitian ini } \\
\text { menunjukkan bahwa jumlah kunjungan wisatawan dan rata-rata lama menginap } \\
\text { wisatawan berpengaruh positif dan signifikan terhadap Pendapatan Asli Dearah (PAD) di } \\
\text { kabupaten Lombok Tengah. }\end{array}$ \\
\hline
\end{tabular}

Corresponding Author:

Alamat : Program Studi Ekonomi Pembangunan, Fakultas Ekonomi dan Bisnis, Universitas Mataram, Jln. Majapahit No.

62 Mataram.

e-mail: ihsanrois@gmail.com 


\section{PENDAHULUAN}

Pariwisata internasional merupakan ekspor yang secara tidak langsung menciptakan aliran mata uang asing ke dalam perekonomian suatu negara tujuan, yang dapat memberikan kontribusi secara langsung terhadap neraca pembayaran. Seperti industri ekspor lainnya, aliran pendapatan ini menciptakan omset usaha, pendapatan rumah tangga, pekerjaan, dan pendapatan pemerintah (Archer, Brian, et. Al., 2004).

Pariwisata pada saat ini merupakan kebutuhan utama yang sangat pentingnya bagi perekonomian dunia.Di beberapa Negara, industri pariwisata menjadi salah satu industri terbesar selain eksportir jasa.Para ahli ekonomi telah meneliti mengenai kontribusi langsung yang diberikan oleh industri pariwisata terhadap sektor ekonomi nasional (Dritsakis, Nikolaos, 2004). Organisasi Pariwisata Dunia (World Tourism Organization/UNWTO) memperkirakan wisatawan internasional akan mencapai 1,8 miliar pada tahun 2030 dengan tingkat pertumbuhan kunjungan diperkirakan 3,3 persen per tahun. Untuk wilayah Asia dan Pasifik diperkirakan dapat dicapai pertumbuhan yang lebih tinggi yaitu 4,9 persen, bahkan akan lebih tinggi untuk negara-negara tertentu (Nesparnas, 2014). Hal tersebut tentunya akan berdampak pada kegiatan perekonomian negara-negara lain, termasuk Indonesia. Sementara tantangan domestik Indonesia diwarnai dengan pertumbuhan ekonomi yang melambat. Berdasarkan laporan Indeks Daya Saing Global 2016-2017 yang dirilis World Economic Forum(WEF), yang menunjukkan daya saing Indonesia merosot dari peringkat 37 menjadi 41 dari 138 negara. Kondisi ini menunjukkan Indonesia harus lebih keras lagi untuk dapat bersaing dalam perekonomian dunia.

Kabupaten Lombok Tengah yang menjadi salah satu target potensi pariwisata di Indonesia yang terletak di provinsi Nusa Tenggara Barat, merupakan salah satu kabupaten yang mempunyai potensi dikembangkannya industri pariwisata. Mengingat pulau Lombok pada saat ini merupakan destinasi favorit bagi wisatawan domestik maupun asing.Dan untuk memfasilitasi para wisatawan, perlunya dikembangkan industri pariwisata berupa hotel dan restoran untuk mengakomodasi para wisatawan.

Pengembangan pariwisata di Kabupaten Lombok Tengah diikuti dengan berkembangnya jumlah, restoran serta obyek-obyek wisata seiring dengan bertambahnya jumlah wisatawan yang berkunjung ke kabupaten tersebut.Hal tersebut diharapkan mempunyai dampak yang positif terhadap peningkatan jumlah Pendapatan Asli Daerah (PAD) yang diterima oleh kabupaten Lombok Tengah. Berdasarkan uraian pada latar belakang, maka rumusan masalah dalam penelitian ini adalah sebagai berikut: "Bagaimanakah dampak pengembangan pariwisata terhadap Pendapatan Asli Daerah (PAD) di kabupaten Lombok Tengah tahun 2002-2016 ?

Adapun Tujuan dari kajian ini adalah untuk menganalisis pengaruh pengembangan pariwisata terhadap Pendapatan Asli Daerah (PAD) di kabupaten Lombok Tengah.

\section{Kajian Teori}

\section{TINJAUAN PUSTAKA}

Pariwisata sebagai suatu konsep dapat dipandang dari berbagai perspektif yang berbeda.Pariwisata adalah suatu perjalanan dari rumah, terutama untuk bermaksud bisnis atau bersantai. Pariwisata adalah suatu bisnis dalam penyediaan barang dan jasa bagi wisatawan dan menyangkut setiap pengeluaran oleh atau wisatawan atau pengunjung perjalanan (Lundberg, 1997). Pertumbuhan pariwisata cenderung terjadi ketika pariwisata menunjukkan pengaruh terhadap perekonomian secara keseluruhan dalam bentuk suatu kesatuan dan eksternalitas lainnya (Marin, 1992). Keuntungan besar dari sektor pariwisata adalah merupakan tersedianya lapangan pekerjaan, sehingga terjadi peningkatan produksi yang dicapai dengan peningkatan tenaga kerja.Hal ini menguntungkan suatu perekonomian di dalam menurunkan tingkat pengangguran, dan meningkatnya upah di sektor jasa, serta mendorong mobilitas di seluruh 
sektor. Dari sudut pandang ekonomi makro, pariwisata menghasilkan pertumbuhan ekonomi dan lapangan kerja (Martin, et. Al., 2004). Motivasi, preferensi dan persepsi wisatawan mempengaruhi sumber daya pariwisata sendiri dalam arti bahwa wisatawan menentukan apa yang menjadi daya tarik wisata dan nilanya di tempat tujuan. Wisatawan tidak pernah membeli "sumber", mereka pergi ke tujuan wisata, melihat atraksi di dalam kunjungan dan menggunakan fasilitas yang ada di tempat tujuan wisata (Liu, 2003).

Wisatawan merupakan individu/kelompok yang mempertimbangkan dan merencanakan daya beli yang dimilikinya untuk perjalanan rekreasi dan berlibur, motivasi perjalanan yang pernah ia lakukan sebelumnya, menambah pengetahuan, tertarik oleh suatu daerah tujuan wisata yang dapat menarik pengunjung di masa yang akan datang. (G.A Schmoll dalam Yoeti, 1977).Belanja wisatawan di daerah tujuan wisatanya juga akan meningkatkan pendapatan dan pemerataan pada masyarakat setempat secara langsung maupun tidak langsung melalui dampak berganda (multiplier effect). Dimana di daerah pariwisata dapat menambah pendapatannya dengan menjual barang dan jasa, seperti restoran, hotel, pramuwisata dan barang-barang souvenir. Dengan demikian, pariwisata harus dijadikan alternatif untuk mendatangkan keuntungan bagi daerah tersebut (Spillane, 1987).

Roerkaerts dan Savat dalam (Spillane, 1987) menjelaskan bahwa manfaat yang dapat diberikan sektor pariwisata adalah: (a) menambah pemasukan dan pendapatan, baik untuk pemerintah daerah maupun masyarakatnya. Penambahan ini bisa dilihat dari meningkatnya pendapatan dari kegiatan usaha yang dilakukan masyarakat, berupa penginapan, restoran, dan rumah makan, pramuwisata, biro perjalanan dan penyediaan cinderamata. Bagi daerah sendiri kegiatan usaha tersebut merupakan potensi dalam menggali PAD, sehingga perekonomian daerah dapat ditingkatkan, (b) membuka kesempatan kerja, industri pariwisata merupakan kegiatan mata rantai yang sangat panjang, sehingga banyak membuka kesempatan kerja bagi masyarakat di daerah tersebut, (c) menambah devisa negara, semakin banyaknya wisatawan yang datang, maka makin banyak devisa yang akan diperoleh, (d) Merangsang pertumbuhan kebudayaan asli, serta menunjang gerak pembangunan daerah. Shella, Zelvian, dkk ( 2014) melakukan penelitian mengenai Faktor-faktor yang mempengaruhi penerimaan daerah sektor pariwisata kota Banda Aceh. Dengan menggunakan alat analisis regresi linier berganda, hasilnya menunjukkan bahwa jumlah wisatawan, jumlah hotel dan lama tinggal wisatawan mempengaruhi penerimaan daerah sektor pariwisata di kota Banda Aceh.

Rosa, Del Yani, dkk (2016) melakukan penelitian mengenai analisis dampak sektor pariwisata terhadap Pendapatan Asli Daerah (PAD) Kabupaten Pesisir Selatan tahun 2004-2014. Hasil analisis menunjukkan bahwa jumlah obyek wisata dan jumlah wisatawan mempunyai pengaruh terhadap Pendapatan Asli Daerah (PAD), sedangkan PDRB tidak mempunyai mempunyai pengaruh terhadap Pendapatan Asli Daerah (PAD). Proenca dan Soukiazis (2008) meneliti dampak pariwisata terhadap pertumbuhan pendapatan perkapita di wilayah Portugis dan menarik kesimpulan bahwa pariwisata dapat dianggap sebagai solusi alternatif untuk meningkatkan pertumbuhan regional di Portugal, jika karakteristik pendapatan sektor ini meningkat.

Kontribusi pariwisata terhadap pembangunan ekonomi di suatu wilayah memerlukan analisis keterkaitan antara sektor pariwisata dan sektor lainnya, pemahaman tentang lokasi spasial kegiatan pariwisata dan identifikasi penerima dampak ekonomi dan lainnya.Ini berarti jika pariwisata memiliki pengaruh besar terhadap perekonomian suatu negara atau wilayah tertentu, hal itu seharusnya memiliki hubungan yang kuat dengan ekonomi domestik lainnya. Oleh karena itu, pariwisata dapat menjadi sesuatu yang dapat memberikan perubahan bagi pembangunan nasional dan regional, ketenagakerjaan, pendapatan, surplus neraca pembayaran dan perkembangan infrastruktur penting 
dan menguntungkan bagi penduduk lokal dan pengunjung. (Glasson et al., 1995 )

\section{METODE PENELITIAN}

Jenis penelitian yang digunakan dalam penelitian ini adalah dengan menggunakan analisis asosiatif dengan pendekatan penelitian ini adalah kuantitatif dengan jenis penelitian adalah ekplanatori yang bertujuan untuk mengetahui dan menjelaskan dampak pengembangan pariwisata terhadap Pendapatan Asli Daerah (PAD).

Lokasi penelitian dilakukan di Kabupaten Lombok Tengah, Provinsi Nusa Tenggara Barat.Kabupaten Lombok Tengah.Jenis data yang digunakan dalam penelitian ini adalah data sekunder yang di dapat dari instansi yang berkaitan dengan penelitian ini. Data yang digunakan adalah data time series selama kurun waktu 15 tahun dari tahun 2002-2016.

Dengan penelitian asosiatif dapat dibangun suatu teori yang berfungsi untuk menjelaskan, meramalkan dan mengontrol suatu gejala/fenomena.Sedangkan alat analisis yang digunakan dalam penelitian ini adalah regresi linier berganda yang merupakan. Model umum dari Regresi Linier Berganda adalah sebagai berikut:

$Y=\beta_{0}+\beta_{1} X_{1}+\beta_{2} X_{2}+\beta_{3} X_{3}+\beta_{4} X_{4}+\mu$ Dimana:

$Y=$ Jumlah Pendapatan Asli Daerah $\mathrm{X} 1$ = Jumlah kunjungan wisatawan $\mathrm{X} 2=$ jumlah kamar hotel dan restoran $\mathrm{X} 3=$ jumlah obyek wisata

$\mathrm{X} 4=$ rata-rata lama menginap wisatawan $\mu=$ term of error $\beta_{0}=$ intecept

$\beta_{1}, \beta_{2}, \beta_{3}, \beta_{4}$, adalah koefisien regresi

\section{HASIL DAN PEMBAHASAN \\ Uji Asumsi Klasik}

1. Uji Normalitas

Uji normalitas digunakan untuk mengetahui suatu model yang digunakan dalam penelitian apakah berdistribusi normal atau tidak.Berdasarkan hasil olahan data dengan menggunakan program software Eviews 7 bahwa nilai Jarque-Bera sebesar 0.9919965 dengan tingkat probabilitas sebesar 0.608972 . Nilai Chi square dengan melihat jumlah variabel dependen sebanyak 4 variabel yang digunakan dalam penelitian ini, maka nilai nilai chi square pada tabel sebesar 9.48773 dalam nilai signifikan sebesar 0.05 . Artinya bahwa nilai JarqueBera lebih kecil dari nilai chi square yaitu $0.9919965<9.48773$ sehingga dapat disimpulkan bahwa dalam dalam penelitian ini mempunyai distribusi normal. Uji normalitas dapat dilihat pada grafik 1 sebagai berikut:

daerah dalam membuat perencanaan dan pola kebijakan pemerintah daerah terutama dalam pengelolaan keuangan daerah yang sekaligus dapat berfungsi sebagai bahan evaluasi sampai sejauhmana tingkat kemandirian dan desentralisasi fiskal daerah di era otonomi daerah sekarang ini. Selanjutnya akan ditunjukkan perkembangan Anggaran Pendapatan Kabupaten Lombok Timur selama lima tahun terakhir sesuai tabel di bawah ini.

Grafik 1. Uji Normalitas

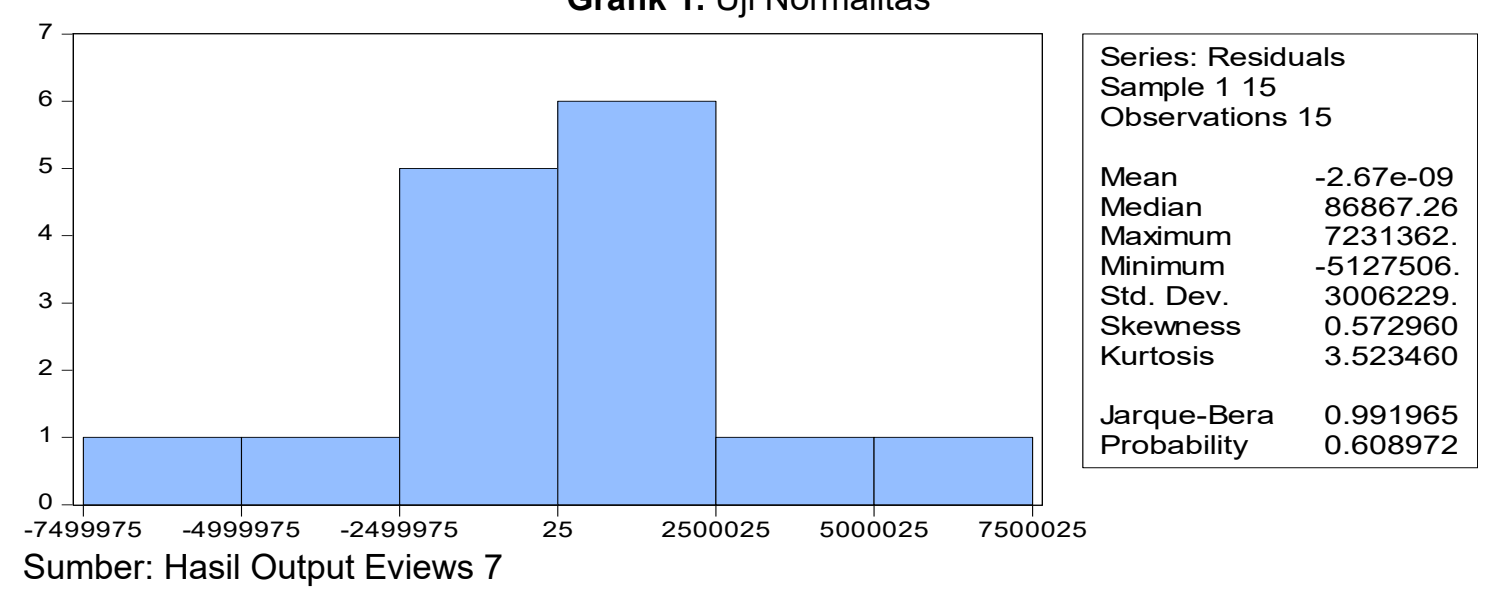




\section{Uji Multikolinieritas}

Multikolinieritas artinya bahwa terdapat hubungan linier yang sempurna atau pasti antara beberapa atau semua variabel yang menjelaskan model regresi.Adanya multikolinieritas dalam model mengakibatkan sangat sulit memisahkan pengaruh dari

masing-masing variabel yang bebas secara individu terhadap variabel terikat.Jika koefisien korelasi antara masing-masing variabel bebas lebih besar dari 0.8 artinya bahwa terjadi multikolinieritas dalam model regresi. Metode yang digunakan untuk mendeteksi multikolinieritas dilakukan dengan melihat tabel 2 sebagai berikut:

Tabel 2. Korelasi Matriks

\begin{tabular}{|c|c|c|c|c|}
\hline & X1 & X2 & X3 & X4 \\
\hline X1 & 1.000000 & 0.769216 & 0.872178 & 0.634223 \\
\hline X2 & 0.769216 & 1.000000 & 0.884796 & 0.895263 \\
\hline X3 & 0.872178 & 0.884796 & 1.000000 & 0.817043 \\
\hline X4 & 0.634223 & 0.895263 & 0.817043 & 1.000000 \\
\hline
\end{tabular}

Sumber: Hasil output Eview 7

Berdasarkan tabel 2 di atas dapat dilihat bahwa tidak ada variabel yang mempunyai nilai korelasi tidak lebih dari 0.8 , sehingga dapat disimpulkan bahwa tidak terjadi multikolinieritas pada model regresi.

\section{Uji Heteroskedastisitas}

Uji heteroskedastisitas digunakan dengan tujuan untuk mengetahui apakah model dalam penenlitian ini mengandung gejala heteroskedastisitas atau tidak.Untuk mengujinya digunakan uji Glesjer yaitu dengan cara meregresikan antara variabel independen dengan nilai absolut residualnya.Jika nilai signifikan antara variabel independen dengan absolut residualnya lebih dari 0.05 maka tidak terjadi masalah heteroskedastisitas.

Tabel 3. Heteroskedasticity Test: Glejser

\begin{tabular}{llll}
\hline \hline F-statistic & 3.068193 & Prob. F(4,10) & 0.0685 \\
Obs*R-squared & 8.265319 & Prob. Chi-Square(4) & 0.0823 \\
Scaled explained SS & 5.712626 & Prob. Chi-Square(4) & 0.2217 \\
\hline \hline
\end{tabular}

Sumber: Hasil Output Eviews 7

Pada hasil uji heteroskedastisitas yang menggunakan uji Glesjer dapat dilihat bahwa probalilitas $\mathrm{F}$ atau probabilitas chisquare > 0.05, maka dapat disimpulkan bahwa $\mathrm{H}_{0}$ diterima atau tidak terjadi gejala heteroskedastisitas karena 3.048193 > 0.05 .

\section{Uji Autokorelasi}

Untuk menguji adanya autokorelasi atau tidak dalam model regresi, digunakan serial Correlation LM test. Hipotesis yang dibangun dalam pengujian autokorelasi adalah sebagai berikut:

$\mathrm{H}_{0}=$ tidak terdapat autokorelasi
$\mathrm{H}_{1}=$ terdapat autokorelasi

Pengujian ini menggunakan uji serial correlation $L M$ test yang menggunakan statistic Chis-square, dengan membandingkan nilai probabilitas Chisquare pada $\mathrm{Obs}^{*} \mathrm{R}$-square dengan alfa 0.05 . jika probabilitas $>0.05$ maka $\mathrm{H}_{0}$ diterima yang artinya tidak terdapat autokorelasi. Dari hasil uji Serial Correlation LM test dapat diketahui bahwa nilai Obs* R-squared sebesar 3.139412 dengan nilai probabilitas Chi square(2) > 0.05, maka $\mathrm{H}_{0}$ diterima artinya bahwa tidak terdapat autokorelasi.Hasil uji autokorelasi dapat dilihat pada tabel 4 berikut. 
Tabel 4. Breusch-Godfrey Serial Correlation LM Test:

\begin{tabular}{cccc}
\hline \hline F-statistic & 1.058771 & Prob. F(2,8) & 0.3909 \\
Obs*R-squared & 3.139412 & Prob. Chi-Square(2) & 0.2081 \\
\hline \hline
\end{tabular}

Sumber: Hasil Output Eviews 7

Hasil Analisis Data

Untuk melihat dampak pengembangan pariwisata terhadap pendapatan daerah
(PAD) dengan menggunakan model regresi linier berganda diperoleh hasil dalam tabel 4 sebagai berikut:

Tabel 5. Hasil Estimasi Regresi Linier Berganda Variabel Dependen: $Y$

\begin{tabular}{|c|c|c|c|c|c|}
\hline No. & Variabel & Koefisien & t-Statistik & Probabilitas & Keterangan \\
\hline 1 & Konstanta & -27816694 & -3.310508 & 0.0079 & Signifikan \\
\hline 2 & $\mathrm{X} 1$ & 65272.08 & 2.403781 & 0.0371 & Signifikan \\
\hline 3 & $\mathrm{X} 2$ & 681033.5 & 1.613149 & 0.1378 & $\begin{array}{c}\text { Tidak } \\
\text { Signifikan }\end{array}$ \\
\hline 4 & $\mathrm{X} 3$ & -23375.80 & 46366.69 & 0.6251 & $\begin{array}{c}\text { Tidak } \\
\text { Signifikan }\end{array}$ \\
\hline 5 & $\mathrm{X}$ & & & Signifikan \\
\hline $\begin{array}{l}\text { R-squared } \\
\text { Adjusted R-squrared } 0.948105\end{array}$ \\
$\begin{array}{l}\text { F-statistik } \\
\text { Prob(F-statistik) }\end{array}$ \\
\hline
\end{tabular}

Sumber: Sumber: Hasil Output Eviews 7, diolah

$Y=-27816694+65272.08 X 1+681033.5 X 2-23375.80 X 3+7080809 X 4+\mu$

Pada tabel 5 dapat dilihat hasil analisis sebagai berikut:

Pada nilai koefisien c (konstanta) sebesar -2781669, dengan tingkat signifikan lebih kecil dari nilai probabilitas sebesar 0.0079.artinya bahwa jika variabel independen yaitu $\mathrm{X} 1, \mathrm{X} 2, \mathrm{X} 3, \mathrm{X} 4$ bernilai 0 (nol) maka variabel dependen ( $Y$ ) akan bernilai -2781669 .

Koefisien variabel $X 1$ terhadap variabel $Y$ dimana koefisien terdapat nilai sebesar 0.0371 , nilai signifikan lebih kecil dari nilai probabilitas sebesar 0.05 atau nilai $0.00372<0.05$, maka $\mathrm{H}_{a}$ diterima dan $\mathrm{H}_{0}$ ditolak.Maka dapat disimpulkan bahwa variabel X1 memiliki kontribusi dan mempunyai hubungan searah terhadap variabel Y.Artinya bahwa setiap peningkatan jumlah wisatawan sebanyak 1 orang diharapkan akan meningkatkan jumlah Pendapatan Asli Daerah (PAD) sebesar Rp. 65.272.08,-

Koefisien pada variabel $X 2$ terhadap $Y$ dimana koefisien dengan nilai sebesar 681033.5, nilai signifikan lebih besar dari nilai probalibitas sebesar 0.05 atau 0.1378 > 0.05, maka HO ditolak dan Ha diterima.
0.1378. Maka dapat disimpulkan bahwa variabel $\mathrm{X} 2$ tidak mempunyai hubungan yang signifikan terhadap variabel $Y$.

Koefisien pada variabel $\mathrm{X} 3$ dengan nilai koefisien sebesar -23375.80 , dimana nilai signifikan lebih besar dari nilai probabilitas sebesar 0.05 atau $0.6251>0.05$, maka $\mathrm{Ha}$ ditolak dan $\mathrm{HO}$ diterima.maka dapat disimpulkan bahwa variabel $\mathrm{X} 3$ tidak mempunyai hubungan yang signifikan terhadap variabel $Y$.

Koefisien pada variabel $\mathrm{X} 4$ dengan nilai sebesar 7080809 , dimana nilai signifikan lebih besar dari nilai probabilitas sebesar 0.05 atau $0.0037<0.05$, maka $\mathrm{Ha}$ diterima dan $\mathrm{H}_{0}$ ditolak. 0.1378. Maka dapat disimpulkan bahwa variabel $\mathrm{X} 4$ memiliki kontribusi dan mempunyai hubungan searah terhadap variabel Y.Artinya bahwa jika rata-rata lama tinggal wisatawan meningkat sebesar 1 hari, maka kontribusi yang diharapkan terhadap Pendapatan Asli Daerah (PAD) sebesar Rp. 7.080.809,-.

Uji $F$ dapat dilihat pada tabel 5 , dengan nilai probalilitas sebesar 0.0000 ., dengan membnadingkan nilai $F$ tabel dan 
$\mathrm{F}$ hitung dengan tingkat signifikasi alpha 0.05 . Nilai $F$ tabel dapat diperoleh degan cara menghitung derajat kebebasan $(\mathrm{df})=$ (k-1);(n-k), dimana k merupakan jumlah variabel dalam penelitian dan $n$ merupakan jumlah tahun atau rentang waktu pada penelitian maka jumlah yang diperoleh= (5-1);(15-5) maka nilai $F$ tabel $=2.90$ berdasarkan hasil dari olahan data dengan menggunakan Eviews 7 maka diketahui nilai dari $F$ hitung sebesar $64.94411>\mathrm{f}$ tabel sebesar 2.90 dengan tingkat signifikan sebesar $0.0000<0.05$. Maka dapat disimpulkan bahwa variabel independen $(X 1, X 2, X 3, X 4)$ bersama-sama mempunyai pengaruh yang positif dan signifikan terhadap variabel dependen $(Y)$.

Dalam Uji determinasi dapat dilihat bahwa nilai $\mathrm{R}$ squared sebesar 0.962932 memiliki arti bahwa variasi seluruh variabel independen $(X 1, X 2, X 3, X 4)$ dapat mempengaruhi variabel dependen $(Y)$ sebesar $96 \%$ dan sisanya ditentukan oleh factor-faktor lain di luar variabel penelitian.

\section{Pembahasan \\ Pengaruh Jumlah Kunjungan \\ Wisatawan Terhadap Pendapatan Asli Daerah (PAD)}

Koefisien regresi untuk variabel jumlah kunjungan wisatawan adalah sebesar 65272.08 dengan probabilitas sebesar 0.0371 menunjukkan hasil yang signifikan. Artinya bahwa setiap peningkatan jumlah wisatawan sebanyak 1 orang diharapkan akan meningkatkan jumlah Pendapatan Asli Daerah (PAD) sebesar Rp. 65.272.08,-

Hasil penelitian ini sesuai dengan penelitian yang dilakukan oleh Shella, Zelvian, dkk( 2014) yang melakukan penelitian mengenai Faktor-faktor yang mempengaruhi penerimaan daerah sektor pariwisata kota Banda Aceh. Hasilnya menunjukkan bahwa jumlah wisatawan mempengaruhi penerimaan daerah sektor pariwisata di kota Banda Aceh. Rosa, Del Yani, dkk (2016) melakukan penelitian mengenai dampak sektor pariwisata terhadap (PAD) kabupaten Pesisir Selatan tahun 2004-2014, hasilnya menunjukkan bahwa jumlah wisatawan mempunyai pengaruh terhadap pendapatan asli daerah.

\section{Pengaruh Jumlah Hotel Dan Restoran Terhadap Pendapatan Asli Daerah}

Koefisien regresi untuk variabel jumlah hotel dan restoran adalah sebesar 681033.5 dengan probabilitas sebesar 0.1378 menunjukkan hasil yang tidak signifikan.Artinya bahwa jumlah hotel dan restoran tidak dapat menentukan kenaikan ataupun penurunan jumlah pendapatan asli daerah.Tingkat hunian hotel, fasilitas dan jumlah wisatawan yang makan dan minum di restoran yang dapat memberikan pengaruh langsung terhadap pendapatan asli daerah, berupa jumlah pajak yang ditarik dari hotel dan restoran tersebut.

Hasil penelitian ini sesuai dengan penelitian yang dilakukan oleh Wulandari, Sri dan Triandaru, Sigit (2015) mengenai Peran Sektor Pariwsata Dalam Pendapatan Asli Daerah Kabupaten Tabanan 1990-2014, yang menyebutkan bahwa jumlah hotel tidak berpengaruh signifikan terhadap PAD.

Pada dasarnya jumlah hotel dan restoran tidak mempengaruhi besaran nilai pendapatan asli daerah, melainkan lama menginap wisatawan dan belanja wisatawan di dalam mengkonsumsi makan dan minum yang dapat memberikan pengaruh terhadap pendapatan asli daerah. Seperti yang dijelaskan oleh Spillane (1987) bahwa belanja wisatawan di daerah tujuan wisatanya juga akan meningkatkan pendapatan dan pemerataan pada masyarakat setempat secara langsung maupun tidak langsung melalui dampak berganda (multiplier effect). Dimana di daerah pariwisata dapat menambah pendapatannya dengan menjual barang dan jasa, seperti restoran, hotel, pramuwisata dan barang-barang souvenir. Dengan demikian, pariwisata harus dijadikan alternatif untuk mendatangkan keuntungan bagi daerah tersebut.

\section{Pengaruh Jumlah Obyek Wisata Terhadap Pendapatan Asli Daerah (PAD)}

Koefisien regresi untuk variabel jumlah obyek wisata adalah sebesar -23375.80 dengan nilai probabilitas sebesar 0.6251 menunjukkan hasil yang tidak signifikan. Hasil penelitian ini sesuai dengan 
penelitian yang dilakukan oleh Suherlan, herlan (2016) yang menyebutkan bahwa jumlah obyek wisata tidak mempunyai pengaruh yang signifikan terhadap Pendapatan Asli Dearah (PAD). Bahwa bukan jumlah dari obyek wisata yang dapat meningkatkan pendapatan asli daerah melainkan jumlah wisatawan yang datang mengunjungi obyek wisata tersebut dengan membeli karcis masuk dan penggunaan fasilitas lainnya yang berbayar.

Seperti yang dijelaskan dalam UU no. 28 tahun 2001 mengenai pajak daerah dan retribusi daerah. Pendapatan obyek pariwisata adalah merupakan sumber penerimaan obyek pariwisata yang berasal dari retribusi karcis masuk, retribusi parkir dan pendapatan lain-lain yang sah berasal dari obyek pariwisata tersebut. Sproule-Jones dan White (1997) mengatakan bahwa retribusi adalah semua bayaran yang dilakukan bagi perorangan dalam menggunakan layanan yang mendatangkan keuntungan langsung dari layanan itu

\section{Pengaruh Rata-Rata Lama Tinggal Wisatawan Dengan Pendapatan Asli Daerah (PAD)}

Koefisien rata-rata lama menginap wisatawan adalah sebesar 7080809 dengan nilai probabilitas sebesar 0.0037 menunjukkan hasil yang signifikan. Artinya bahwa jika rata-rata lama tinggal wisatawan meningkat sebesar 1 hari, maka kontribusi yang diharapkan terhadap Pendapatan Asli Daerah (PAD) sebesar Rp. 7.080.809,-.

Hasil penelitian ini sesuai dengan penelitian yang dilakukan oleh Shella, Zelvian, et. Al (2014) yang menunjukkan bahwa rata-rata menginap wisatawan mempengaruhi penerimaan daerah sektor pariwisata di kota Banda Aceh. Menurut Theobald (2005) Data pengeluaran wisatawan merupakan salah satu indikator terpenting yang digunakan untuk memantau dan mengevaluasi dampak pariwisata terhadap suatu perekonomian dan pada berbagai segmen industri pariwisata yang representatif. Hal tersebut mendefinisikan bahwa pengeluaran pariwisata sebagai "total pengeluaran konsumsi yang dilakukan oleh wisatawan selama perjalanannya dan menginap di tempat tujuan".

\section{KESIMPULAN DAN SARAN \\ Kesimpulan}

Berdasarkan hasil analisis kuantitatif yang telah diuraikan, maka dapat ditarik kesimpulan sebagai berikut:

1. Jumlah kunjungan wisatawan domestik maupun mancanegara mempunyai pengaruh yang positif dan signifikan terhadap Pendapatan Asli Daerah (PAD) di kabupaten Lombok tengah. Hal ini berarti bahwa setiap peningkatan jumlah wisatawan sebanyak 1 orang, diharapkan akan meningkatkan jumlah Pendapatan Asli daerah PAD) sebesar Rp. 65.272.08,--

2. Rata-rata lama tinggal wisatawan di kabupaten Lombok Tengah mempunyai pengaruh yang positif dan signifikan terhadap Pendapatan Asli Daerah (PAD) di kabupaten Lomboh Tengah. Hal ini berarti bahwa setiap peningkatan rata-rata lama tinggal wisatawan sebanyak 1 hari, diharapkan akan meningkatkan jumlah Pendapatan Asli Daerah (PAD) sebesar Rp. 7.080.809,--

\section{Saran}

Sektor pariwisata merupakan sector unggulan yang dapat memberikan sumbangan yang cukup besar terhadap Pendapatan Asli daerah (PAD). Oleh sebab itu untuk lebih meningkatkan peran sector pariwisata terhadap Pendapatan Asli Daerah (PAD) dan dalam rangka menjadikan sector pariwisata tetap menjadi sector unggulan di masa yang akan datang, maka perlu diambil langkahlangkah strategis sebagai berikut:

1. Dari hasil penelitian ini didapatkan bahwa jumlah wisatawan dan ratarata lama menginap wisatawan mempunyai pengaruh terhadap pendapatan asli daerah. Maka perlu dilakukan upaya-upaya untuk lebih meningkatkan jumlah kunjungan wisatawan dan lama menginap wisatawan. Salah satu upaya yang perlu diperhatikan adalah perlunya dilakukan 
promosi-promosi atas obyek wisata, seni dan budaya yang ada di kabupaten Lombok Tengah, sehingga dapat menjadi daya tarik bagi wisatawan untuk datang berkunjung. Serta Jaminan keamanan bagi wisatawan terutama di wilayah pantai kuta yang menjadi daya tarik utama wisatawan, perlu ditingkatkan sehingga menimbulkan kenyamanan dan keamanan bagi wisatawan yang berkunjung ke kabupaten Lombok Tengah. Dalam upaya peningkatan jumlah wisatawan domestik dan mancanegara dan peningkatan rata-rata lama menginap wisatawan di kabupaten Lombok Tengah.

2. Sedangkan dari hasil penelitian yang telah dilakukan bahwa jumlah hotel dan restoran serta jumlah obyek wisata tidak mempunyai pengaruh yang signifikan terhadap pendapatan asli daerah. Adapun upaya yang harus dilakukan agar hotel-hotel yang ada di kabupaten Lombok Tengah baik hotel bintang maupun melati, untuk dapat meningkatkan kualitas pelayanan dan keamanan agar para tamu dapat merasakan kenyamanan dan rasa aman untuk tinggal lebih lama di hotel tersebut. Fasilitas yang diberikan dapat berupa layanan untuk transportasi menuju lokasi wisata, diving, surfing dan lain sebagainya. Begitu juga dengan restoran harus menjaga kualitas makanan dan minuman serta variasi jenis makanan untuk dapat memenuhi kebutuhan makan dan minum wisatawan. Dalam hal jumlah obyek wisata perlunya ditunjang dengan saran transportasi yang memadai untuk menjangkau obyek-obyek wisata yang letaknya saling berjauhan dari lokasi penginapan. Serta perbaikan jalan untuk menuju lokasi obyek wisata.

\section{DAFTAR PUSTAKA}

Archer, Brian, et. Al. (2004). The Positive and Negative Impacts of Tourism, Global Tourism third edition, edited by William F. Theobald.

Dritsakis, Nikolaos (2004). Tourism As a Long Run Economic Growth Factor: an Empirical 3, 305-316.

Enders, Walter. (2004). Applied Econometrics Time Series, $2^{\text {nd }}$. Ed. New York: Wiley.

Gujarati, Damodar N. (2004). Basic Econometrics, $4^{\text {th }}$ ed. The McGraw-Hill Companies.

Glasson, J., Godfrey, K. \& Goodey, B. (1995). Towards Visitor Impact Management: Visitor Impacts, Carrying Capacity and Management Responses in Europe's Historic

Towns and Cities. England: Avebury. 189 pp.

Liu, Zhenhua (2003). Sustainable tourism development: a critique. Journal of Sustainable Tourism, 11 (6). pp. 459-475. ISSN 0966-9582.

Lundberg, E Donald, et. al. (1997). Ekonomi Pariwisata. PT.Gramedia. Jakarta. Pustaka Umum.

Marin, D. (1992). Is The Export-led Hypothesis Valid for Industrialized Countries? Review of Economics and Statistics,74,678-688. 
88 | Ifsan Rois, Luluk Fadliyanti,Bq.Saripta wijimulawiani/Dampak Pengembangan Pariwisata....

Martin, et. Al. (2004). Tourism and Economic Growth in latin American Country: A Panel Data Approach. Nota di Lavoro, Fondazione Eni Mattei, no. 26, 2004.

Proenca, S., and Soukiazis, E. (2008), 'Tourism as an alternative source of regional growth in Portugal: a panel data analysis at NUTS II and III levels', Portuguese Economic Journal, Vol 7, No 1, pp 43-61.

Rosa, Del Yani, dkk. (2016). Analisis Dampak Sektor Pariwisata Terhadap Pendapatan Asli Daerah (PAD) Kabupaten Pesisir Selatan Tahun 2000-2014. Jurnal Ekonomi dan Bisnis Dharma Andalas, Vol. 18, No.1, Januari 2016.

Shella, Zelvian, dkk. (2014). Faktor-Faktor Yang Mempengaruhi Penerimaan Daerah SektorSektor Pariwisata Kota Banda Aceh. Jurnal Ekonomi Pasca Sarjana Universitas Syiah Kuala, Vol. 2, No. 3, pp. 39-48, Agustus 2014, ISSN 23020172

Spillane, J James (1987).Ekonomi Pariwisata Sejarah dan Prospeknya, Kanisius, Yogyakarta, hal. 134.

Yoeti, Oka A. (1977).Perencanaan dan Pengembangan Pariwisata, PT. Pradnya Paramita, Jakarta.

,Laporan Akuntabilitas Kinerja Kementerian Pariwisata Tahun 2015 (Lakip), www.kemenpar.go.id

.Neraca Satelit Pariwisata Nasional (Nesparnas) 2014, Kementerian Pariwisata, www.parekraf.go.id 